\title{
Influence of dye and nylon fibers on microwave-cured acrylic resin proper- ties
}

\author{
Influência de corante e fibras de nylon nas propriedades de uma resina acrílica polimerizada por micro-ondas
}

\author{
Carmen Beatriz Borges FORTES' \\ Fabrício Mezzomo COLLARES \\ Vicente Castelo Branco LEITUNE'1 \\ Juliana Gehlen WALCHER ${ }^{1}$ \\ Stéfani Becker RODRIGUES ${ }^{1}$ \\ Susana Werner SAMUEL ${ }^{1}$ \\ Cesar Liberato PETZHOLD² \\ Valter STEFANI ${ }^{2}$
}

\section{ABSTRACT}

\section{Objective}

The aim of this study is to analyze if both color and nylon fibers have an influence on microwave-cured acrylic resin properties.

\section{Methods}

Rectangular and disk-shaped specimens were prepared using acrylic resins; medium pink with and without nylon fibers and colorless without nylon fibers. To obtain the rectangular specimens, a stainless steel die was used with the following dimensions: $64 \times 10 \times 3 \mathrm{~mm}( \pm 0.5 \mathrm{~mm}$ ). To obtain disk-shaped specimens, a die $50 \mathrm{~mm}( \pm 0.5 \mathrm{~mm})$ in diameter and $0.5 \mathrm{~mm}( \pm 0.05 \mathrm{~mm})$ thick was employed. They were randomized to form groups: control (colorless acrylic) and experimental (medium pink, with and without nylon fibers), with each group consisting of ten (10) specimens rectangular in shape and five (5) disk-shaped. They were analyzed in six (6) assays (izod impact strength, $n=10 ;$ Knoop hardness, $n=10$; glass transition temperature, $n=3$; water sorption and solubility, $n=5$; degree of monomer/polymer conversion, $n=1$; flexural strength and flexural modulus, $n=10$ ). All variables were subjected to the analysis of variance test followed by Tukey's multiple comparison test, at a $5 \%$ level of significance.

\section{Results}

The analysis of the monomer/polymer degree of conversion did not reveal any difference between the three groups of resins (medium pink, with and without nylon fibers and colorless resin); it was approximately 88\%. The results did not show significant differences between the groups for each variable $(p>0.05)$.

\section{Conclusion}

The results showed that color and presence of nylon fibers in acrylic resins did not affect the properties analyzed in this study.

Indexing terms: Acrylic resins. Microwave. Nylons.

\section{RESUMO}

\section{Objetivo}

Analisar se corantes e fibras de nylon influenciam nas propriedades de uma resina acrílica ativada por energia de micro-ondas.

\section{Métodos}

Espécimes retangulares e em forma de disco foram confeccionados em resina acrílica rosa médio com e sem fibras de nylon e incolor sem fibras Para obter os espécimes retangulares, foi utilizada uma matriz de aço inoxidável com as seguintes dimensões: $64 \times 10 \times 3$ ( $\pm 0,5 \mathrm{~mm})$ e para obter os espécimes em forma de disco, foi utilizada uma matriz com $50 \mathrm{~mm}( \pm 0,5 \mathrm{~mm})$ de diâmetro e $0,5 \mathrm{~mm}( \pm 0,05 \mathrm{~mm})$ de espessura. Os mesmos foram randomizados para formar os grupos controle (acrílico incolor sem fibras) e experimentais (rosa médio com e sem fibras), sendo cada grupo composto por dez (10) espécimes retangulares e cinco (5) em forma de disco. Foram os mesmos então submetidos a seis (6) ensaios (resistência ao impacto izod, $n=10$; dureza knoop, $n=10$; temperatura de transição vítrea, $n=3$; sorção e solubilidade, $n=5$; grau de conversão, $n=1$; resistência à flexão e módulo de flexão, $n=10$ ). Todas as variáveis foram submetidas à análise de variância seguida pelo teste de comparações múltiplas de Tukey, com nível de significância de $5 \%$.

\section{Resultados}

O grau de conversão foi de $88 \%$ para os 3 grupos de resinas e os resultados não mostraram diferença estatisticamente significativa entre os mesmos para cada variável $(p>0,05)$.

\section{Conclusão}

Os resultados mostraram que o corante e a presença de fibras de nylon em resina acrílica não afetaram as propriedades analisadas nesse estudo.

Termos de indexação: Resinas acrílicas. Micro-ondas. Nylons.

\footnotetext{
${ }^{1}$ Universidade Federal do Rio Grande do Sul, Faculdade de Odontologia, Departamento de Odontologia Conservadora, Laboratório de Materiais Dentários. Rua Ramiro Barcelos, 2492, Rio Branco, 90035-003, Porto Alegre, RS, Brasil. Correspondência para / Correspondence to: FM COLLARES E-mail: <fabricio.collares@ufrgs.br>.

${ }^{2}$ Universidade Federal do Rio Grande do Sul, Instituto de Química, Departamento de Química Orgânica. Porto Alegre, RS, Brasil.
} 


\section{INTRODUCTION}

The restoration of masticatory function and aesthetics is an important aim in dentistry, mainly when patients present with extensive tooth loss. For a long time polymethylmethacrylate (PMMA) has dominated the field of denture base materials ${ }^{1}$. This material presents adequate strength to withstand masticatory forces, maintains dimensional stability, adequate resilience, biocompatibility and high polishability. It is available in both powder and liquid form for use and processing. The powders are pure polymers, which are clear and adaptable to a wide range of pigments that are used to obtain the various shades of oral tissue and include compounds such as mercury sulfide, cadmium sulfide, cadmium selenide and ferric oxide. Dyes as well as pigments, which are occasionally used, are not as satisfactory, since they tend to leach out of the plastic through the oral fluids, which results in a gradual lightening of the shade ${ }^{2}$. A cross-linking agent may also be added to the monomer component to improve the solvent resistance of the cured polymer and thereby reduce its susceptibility to solvent crazing ${ }^{3}$. In terms of resin strengtheners, materials such as nylon, viscose rayon and polyester have been explored as esthetic fibers. Nylon fibers have been successfully used to match the minute blood vessels of oral mucosa ${ }^{4}$.

Despite the high degree of conversion achieved in dental resins, complete conversion of aliphatic carboncarbon double bonds is, typically, not achieved. The unconverted double bonds remaining in the resin arise from at least two situations, namely unreacted monomers or pendant double bonds at the ends of polymer chains ${ }^{5}$. During polymerization the monomer is reduced. As temperature increases, molecular mobility speeds up, leading to more complete polymerization. With progressive polymerization of the monomer/polymer mix, the same amount of energy is absorbed by less and less monomer. All acrylic resins contain variable residual monomer levels depending on the environment.

A denture base polymer should have a smooth and glassy surface and be capable of matching the natural appearance of soft tissue. The material should be translucent for the best esthetic effect. Color and translucency should be maintained during processing and acrylic resins should not become stained or change color in clinical use ${ }^{6}$.

Therefore, the purpose of this study was to analyze the influence of color and nylon fibers on the acrylic resin properties.

\section{METHODS}

VIPI WAVE acrylic resin (Dental VIPI, São Paulo, SP, Brazil) and (Clássico, São Paulo, Brazil) were used. The experimental specimens were the medium pink acrylic resin (with or without fibers); and the control samples were the colorless acrylic (without dye and nylon fibers in the composition). The specimens, observing each type of acrylic resin, were randomized to form control and experimental groups, with each group consisting of ten (10) specimens of rectangular shape and five (5) disk-shaped.

\section{Specimen preparation}

Rectangular and disk-shape specimens were prepared using acrylic resins; medium pink with nylon fiber, medium pink without nylon fiber and colorless without nylon fibers. To obtain the rectangular specimens, a stainless steel mold was used with the following dimensions: $64 \mathrm{x}$ $10 \times 3 \mathrm{~mm}( \pm 0.5 \mathrm{~mm})$. To obtain disk-shaped specimens, a mold $50 \mathrm{~mm}( \pm 0.5 \mathrm{~mm})$ in diameter and $0.5 \mathrm{~mm}$ $( \pm 0.05 \mathrm{~mm})$ thick was employed. Each stainless steel matrix is reproduced through the addition of silicone, yielding a silicone matrix. This has been included in the flask with type II dental stone (common gypsum). After solidification of the cast, the resin was included in the silicone matrix and the powder/liquid proportion was measured using analytical scales. After adding the resin, the counter-balanced muffle furnace was closed and pressed with a load of $500 \mathrm{~kg}$, and immediately afterwards was opened to remove the excess resin. It was then pressed with a load of $1000 \mathrm{~kg}$ and after 30 minutes the polymerization was initiated. A microwave oven was used (LG, São Paulo, Brazil), with the following specifications: voltage of $120 \mathrm{~V} / 60 \mathrm{~Hz}$, output power of $1400 \mathrm{~W}$, microwave frequency of $2450 \mathrm{MHz}$, magnetron capable of emitting waves in three dimensions, internal capacity of $32 \mathrm{~L}$, turntable $28 \mathrm{~cm}$ in diameter), for the polymerization process. The flask was then placed on the workbench for 4 hours (to cool off completely). After this, each specimen was removed from the oven and abraded using an electric motor to remove the excess resin. The abrasion was carried out using a mounted Cutter (TDV, Pomerode, Santa Catarina, Brazil). Next, the specimens were polished with 280, 400, 600 and 1000 grit wet sandpaper. After this, the samples were measured with a digital caliper: for the rectangular specimens 10 measurements of the thickness were taken, 10 measures of the width and 3 of the length. For the disks, 8 measurements were taken of the diameter and 8 of the thickness, and the average value 
was calculated. This procedure was performed to obtain a more uniform measurement of the specimens. Polishing was performed using abrasive pumice and Spanish white, in order to afford smoothness and surface gloss to the material.

\section{Izod impact strength}

Ten rectangular specimens $(n=10)$ were tested in an EMIC AIC-1 (a universal testing machine), to determine the impact energy required to fracture them. The test was performed according to the specifications of ASTM D256 (American Society Test Methods).

\section{Knoop Hardness}

Five disk specimens $(n=5)$ were tested. MICROMET (Bueller, Munich, Germany) was used to determine Knoop micro-hardness. The values were obtained from 5 measurements on the surface of each of the specimens, one at the center and the rest at a distance of 100 micrometers from the center. A load of $25 \mathrm{~g}$ was applied for 10 seconds.

\section{Glass transition temperature}

Three specimens $(n=3)$ were tested. They were evaluated using the thermal analysis method known as Differential Scanning Calorimetry (DSC). The DSC-4 calorimeter was used to determine the glass transition temperature $(\mathrm{Tg})$, in degrees Celsius $\left({ }^{\circ} \mathrm{C}\right)$. For this analysis, samples of approximately $10 \mathrm{mg}$ were embedded in aluminum capsules and subjected to a temperature range of 50 to 190 degrees Celsius, at a heating rate of 10 or 20 degrees per minute, with the $\mathrm{Tg}$ being calculated in the second heating cycle.

\section{Water sorption and solubility}

Five disk-shaped specimens from each group $(n=5)$ were weighed using an analytical scale and were then conditioned to constant mass in a desiccator placed in an oven at $37^{\circ} \mathrm{C}$ for 24 hours. The specimens were weighed and reweighed until the weight loss was no greater than $0.0002 \mathrm{~g}$ in any 24 hour period. They were immersed in $50 \mathrm{ml}$ of deionized water at $37^{\circ} \mathrm{C}$ for 7 days. Afterwards, the specimens were removed from the water and dried with paper towels, weighed and reconditioned to constant mass in the desiccator.

\section{Degree of monomer/polymer conversion}

The degree of conversion was measured via Raman micro-spectroscopy. One specimen from each group was used ( $n=1)$. The spectrum peaks of double bonds between carbon atoms unreacted $(C=C)$ at around $1650 \mathrm{~cm}-1$, and $\mathrm{C}=0$ bonds at around $1750 \mathrm{~cm}-1$ were analyzed. The percentage of double bonds was determined based on peak areas in the monomer and in the polymer spectra.

\section{Flexural strength and flexural modulus}

Ten specimens $(n=10)$ from each group were tested. The deflection of the specimens was evaluated after immersion in distilled water for $50( \pm 2)$ hours at $37^{\circ} \mathrm{C}$. This test consists of applying an increasing load from zero at a constant speed of $5( \pm 1) \mathrm{mm} / \mathrm{min}$ in the center of the specimen, which is supported at both ends. The load is applied until the specimen ruptures.

\section{Statistical analysis}

All variables were subjected to analysis of variance followed by Tukey's multiple comparison test, at a level of significance of $5 \%$. The results showed no significant difference between the groups for each variable $(p>0.05)$.

\section{RESULTS}

All data are reported in table 1. The monomer/ polymer degree of conversion revealed no difference among the three groups of resins (medium pink with and without nylon fibers and colorless resin); it was approximately $88 \%$.

Table 1. Experimental groups

\begin{tabular}{|c|c|c|c|}
\hline PROPERTIES & FR & NFR & CR \\
\hline $\begin{array}{l}\text { Flexural strenght } \\
\text { (MPa) }\end{array}$ & $98 \pm 9$ & $100 \pm 10$ & $99 \pm 9$ \\
\hline $\begin{array}{l}\text { Flexural modulus } \\
\text { (MPa) }\end{array}$ & $2555 \pm 95$ & $2581 \pm 87$ & $2586 \pm 91$ \\
\hline Izod strenght (J/m) & $99 \pm 9$ & $99 \pm 9$ & $98 \pm 9$ \\
\hline $\begin{array}{l}\text { Microhardness } \\
\text { Knoop (KHN) }\end{array}$ & $21 \pm 1$ & $21 \pm 1$ & $21 \pm 1$ \\
\hline $\begin{array}{l}\text { Glass transition } \\
\text { temperature }\left({ }^{\circ} \mathrm{C}\right)\end{array}$ & $104 \pm 1$ & $104 \pm 1$ & $104 \pm 1$ \\
\hline Sorption $\left(\mu \mathrm{g} / \mathrm{mm}^{3}\right)$ & $26 \pm 1$ & $26 \pm 1$ & $26 \pm 1$ \\
\hline Solubility $\left(\mu \mathrm{g} / \mathrm{mm}^{3}\right)$ & $0.9 \pm 0.1$ & $0.8 \pm 0.1$ & $0.8 \pm 0.1$ \\
\hline
\end{tabular}




\section{DISCUSSION}

Porosities and residual monomer content have been shown as important factors influencing the flexural strength. The processing technique used to polymerize the denture base resin has been found to be an important factor, which can induce stress in the denture base during processing and ultimately lead to fatigue failure ${ }^{7}$. Porosity has been attributed to a variety of factors that include the following: trapped air during mixing, monomer contraction during the polymerization, monomer vaporization associated with exothermic reaction, the presence of residual monomer, insufficient mixing of monomer and polymer, processing temperature higher than $74^{\circ} \mathrm{C}$, inadequate compression in the flask may also cause porosity in denture base resin ${ }^{8}$.

The advantages of polymerizing denture base resin by microwave energy are a greatly reduced polymerization time, a cleaner method of processing and a denture base with superior adaptation to the dental cast ${ }^{9}$. But porosity in acrylic resin is a complex phenomenon of multifactorial origin. It appears to depend partly on the material/polymerization combination method and the press technique used. Once acrylic resin has been polymerized and pores form in its mass, it is very difficult to determine whether the porosity resulted from the material itself, the polymerization cycle, or handling during the pressing procedure ${ }^{10}$.

Adding the monomer to the polymer causes a resin polymerization reaction that occurs without the formation of by products. Nevertheless, conversion of monomer into polymer is generally not complete ${ }^{11}$. The residual monomer has the potential to create irritation, mucosal inflammation and allergic reaction. Clinical symptoms include erythema, erosion and a burning sensation in the oral area ${ }^{12}$. Furthermore, the pigment added to the powder may be another causative factor of hypersensitivity ${ }^{13}$.

\section{REFERENCES}

1. Hazari P, Bhoyar A, Mishra SK, Yadav NS, Mahajan H. A comparison of masticatory performance and efficiency of complete dentures made with high impact and flexible resins: a pilot study. J Clin Diagn Res. 2015 Jun;9(6):ZC29-ZC34. doi: 10.7860/JCDR/2015/12207.6089

2. Bohra PK, Ganesh PR, Reddy MM, Ebenezar AV, Sivakumar G Colour stability of heat and cold cure acrylic resins. J Clin Diagn Res. 2015 Jan;9(1):ZC 12-ZC 15. doi: 10.7860/JCDR/2015/11620.5400

3. Arima T, Hamada T, McCabe JF. The effects of cross-linking agents on some properties of HEMA-based resins. J Dent Res. 1995 Sep;74(9):1597-601.

\section{CONCLUSION}

Taking into consideration that the color and the presence of fibers in the acrylic resins do not influence the degree of conversion, we could infer that the quantity of residual monomer is similar also. So, the presence of nylon fibers and color do not appear to decrease the acrylic resin properties.

The plasticizing effect of absorbed water is a wellknown process and has been implicated in the reduction of mechanical properties of denture base polymers submitted to microwave disinfection ${ }^{14}$. It is known that the unreacted monomer may act as a plasticizer, thereby increasing the resilience ${ }^{15}$ and decreasing the strength of the polymerized resin ${ }^{16}$. It may be concluded that color and the presence of nylon fibers in acrylic resins did not affect the properties analyzed in this study.

\section{Collaborators}

CBB FORTES participated in the study design development, laboratory tests and manuscript preparation. FM COLLARES participated in the study design development, manuscript preparation and final review; VCB LEITUNE participated in the study design development, data interpretation and manuscript final review; JG WALCHER participated in the data interpretation and manuscript preparation; SB RODRIGUES participated in the study design development, data interpretation and manuscript preparation; SM SAMUEL participated in the study design development and manuscript final review; $\mathrm{CL}$ PETZHOLD participated in the study design development, data interpretation and manuscript final review and $V$ STEFANI participated in the study design development, data interpretation and manuscript final review.

4. Dogan OM, Bolayir G, Keskin S, Dogan A, Bek B, Boztug A. The effect of esthetic fibers on impact resistance of a conventional heat-cured denture base resin. Dent Mater J. 2007 Mar;26(2):2329. doi: $10.4012 / \mathrm{dmj} .26 .232$

5. Collares FM, Portella FF, Leitune VC, Samuel SM. Discrepancies in degree of conversion measurements by FTIR. Braz Oral Res. 2014;28:9-15. doi: 10.1590/S1806-83242013000600002

6. Sepulveda-Navarro $\mathrm{WF}$, Arana-Correa $\mathrm{BE}$, Borges $\mathrm{CP}$, Jorge $\mathrm{JH}$, Urban VM, Campanha NH. Color stability of resins and nylon as denture base material in beverages. J Prosthodont. 2011 Dec;20(8):632-8. doi: 10.1111/j.1532-849X.2011.00791.x

7. Banerjee R, Banerjee S, Prabhudesai PS, Bhide SV. Influence of the processing technique on the flexural fatigue strength of denture 
base resins: an in vitro investigation. Indian J Dent Res. 2010 JulSep;21(3):391-5. doi: 10.4103/0970-9290.70810

8. Singh S, Palaskar JN, Mittal S. Comparative evaluation of surface porosities in conventional heat polymerized acrylic resin cured by water bath and microwave energy with microwavable acrylic resin cured by microwave energy. Contemp Clin Dent. 2013 Apr;4(2):147-51. doi: 10.4103/0976-237X.114844

9. Compagnoni MA, Barbosa DB, de Souza RF, Pero AC. The effect of polymerization cycles on porosity of microwave-processed denture base resin. J Prosthet Dent. 2004 Mar;91(3):281-5.

10. Yannikakis S, Zissis A, Polyzois G, Andreopoulos A. Evaluation of porosity in microwave-processed acrylic resin using a photographic method. J Prosthet Dent. 2002 Jun;87(6):613-9. doi: 10.1067/ mpr.2002.124490

11. Goncalves TS, de Menezes LM, Silva LE. Residual monomer of autopolymerized acrylic resin according to different manipulation and polishing methods. An in situ evaluation. Angle Orthod. 2008 Jul;78(4):722-7. doi: 10.2319/0003-3219(2008)078[0722:RMOA $\mathrm{AR}] 2.0 . \mathrm{CO} ; 2$

12. Ica RB, Ozturk F, Ates B, Malkoc MA, Kelestemur U. Level of residual monomer released from orthodontic acrylic materials. Angle Orthod. 2014 Sep;84(5):862-7. doi: 10.2319/060713435.1
13. Retamoso LB, da Cunha Tde M, Pithon MM, dos Santos RL, Martins FO, Romanos MT, et al. In vitro cytotoxicity of selfcuring acrylic resins of different colors. Dental press journal of orthodontics. 2014; 19: 66-70.

14. Pavarina AC, Neppelenbroek $K H$, Guinesi AS, Vergani $C E$, Machado AL, Giampaolo ET. Effect of microwave disinfection on the flexural strength of hard chairside reline resins. Journal of dentistry. 2005; 33: 741-8.

15. Phoenix RD, Mansueto MA, Ackerman NA, Jones RE. Evaluation of mechanical and thermal properties of commonly used denture base resins. Journal of prosthodontics : official journal of the American College of Prosthodontists. 2004; 13: 17-27.

16. Takahashi Y, Chai J, Kawaguchi M. Equilibrium strengths of denture polymers subjected to long-term water immersion. The International journal of prosthodontics. 1999; 12: 348-52.

Received on: 2/5/2016

Final version resubmitted on: 12/7/2016

Approved on: 22/8/2016 